Faculdade de Ciências Econômicas UFRGS
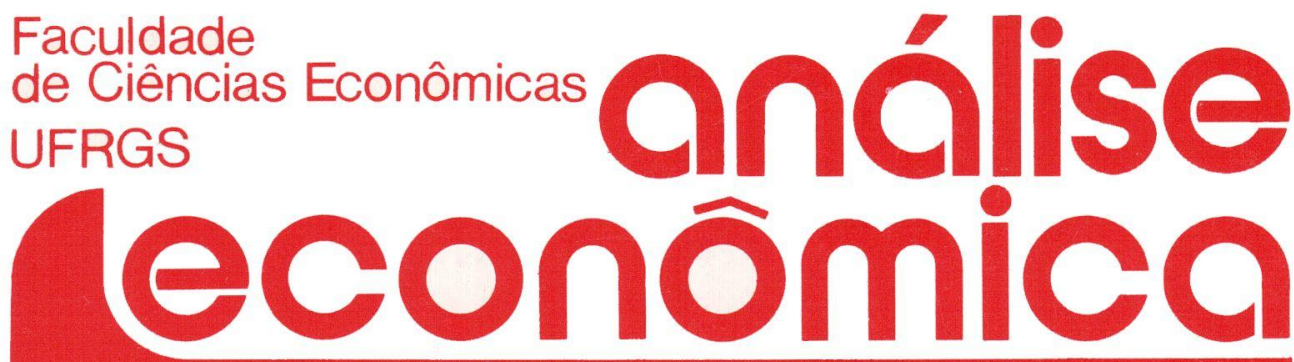

nesta edição:

- POLIITICA SALARIAL:

Roberto Camps Moraes

- DIVIDA EXTERNA:

Yeda Rorato Crusius

-- MECANISMO DAS

RETIFICACCÖES ORÇAMENTÁRIAS:

Manoel Marques Leite

- CREDITO RURAL: Zung Che Yee

- INDL'STRIA E CRISE ATUAL: Claudio F. Accurso
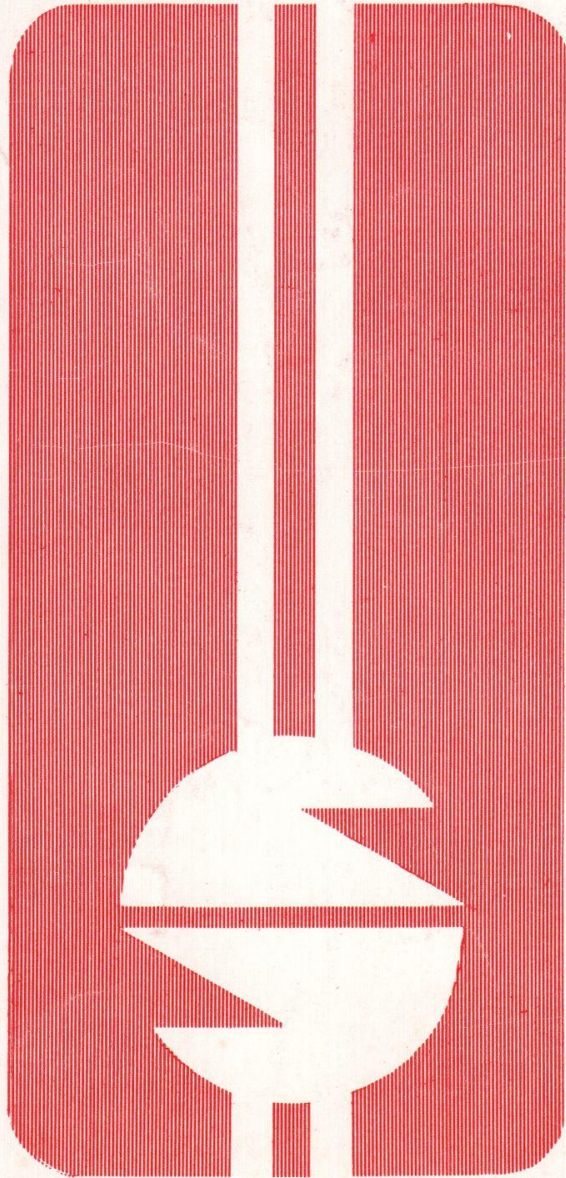

anv 1 
DIRETOR DA FACULDADE DE CIÊNCIAS ECONÓMICAS:

Prof. Antônio Carlos Santos Rosa

VICE-DIRETOR: Prof. Nelson Rokembach

CHEFE DO DEPARTAMENTO DE CIÉNCIAS ECONÔMICAS:

Prof. Renato Batista Masina

CONSELHO EDITORIAL: Prof. Pedro Cezar Dutra Fonseca (Presidente)

Prof. Achyles Barcelos da Costa

Prof. Carlos Augusto Crusius

Prof. Claudio Francisco Accurso

Prof. Edgar Augusto Lanzer

Prof. Ernani Hickmann

Prof. Nali de Jesus de Souza

Prof. Nuno Renan L. de Figueiredo Pinto

Profa Otilia Beatriz Kroeff Carrion

Prof. Roberto Camps Moraes

Profa Yeda Rorato Crusius

ANÁLISE ECONÓMICA é uma publicação semestral da Faculdade de Ciências Econômicas da Universidade Federal do Rio Grande do Sul, visando divulgar estudos e pesquisas de seu corpo docente e discente na área de Economia. Aceitam-se, entretanto, artigos e resenhas bibliográficas de economistas e técnicos não vinculados à Instituição. As matérias assinadas são de responsabilidade exclusiva dos autores. E permitida a reprodução: parcial para fins didáticos.

Toda a correspondência, material para publicação, assinaturas e permutas devem ser dị̣igidas a:

Prof. PEDRO CEZAR DUTRA FONSECA

Revista Análise Econômica

Avenida João Pessoa, $52-3$ ? andar

90.000 - Porto Alegre (RS) - Brasil

Esta edição é uma cortesia do grupo

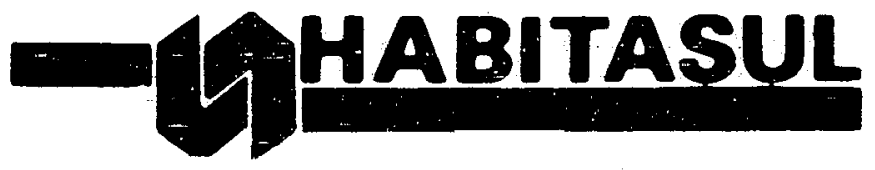




\section{DIVIDA EXTERNA BRASILEIRA: ELEMENTOS PARA DISCUSSÃO}

Recebido para publicação em 01/09/82

Yeda Rorato Crusius *

O objetivo do presente artigo é apresentar elementos para duscutir as questões relacionadas com a dívida externa brasileira, considerando o período que se estende de 1937 a 1981 . Ao identificar a natureza e a composição da dívida externa do Brasil, por períodos representativos das fases de deservolvimento interno, pretende-se apontar as conseqüências do crescimento dessa dívida para a gerência da pol ítica interna de estabilização. Assim, são consideradas as al ternativas atualmente sugeridas para solucionar o problema da "asfixia cambial" por que passa o balanço de pagamentos brasileiro, alternativas que diferem conforme a direção que se queira dar ao rumo do desenvolvimento econômico nacional.

$O$ artigo se divide nas seguintes partes: (1) um breve histórico das relaçồ do Brasil com seus parceiros comerriais mais importantes desde 1937 identificando-se os períodos em que se alteram tanto as condiçōes intel internos; (2) um estudo da evolução das contas do balanço de pagamentos brasileiro e suas relações com a dívida externa; (3) um perfil da divida externa atual, a partir de sua composição e dos indicadores de capacidade de endividamento e de pagamento que sugere; e (4) a indicação da margem de manobra com que contam as autoridades da área econômica para dar continuidade à sua opção de "pagar as contas em dia", e da alternativa que se sugere a esta opção.

- Professora do Curso de Pós-Graduaçáo em Economia e do Departamento de Ciências Econômicas da UFRGS. A autora agradece às sugestöes dos professores Arv Burger e Carlos Augusto Cr:csius. 


\section{UM BREVE HISTORICO}

O Brasil, respeitadas as suas particularidades, enquadra-se no bloco dos países denominados de "periferia", sendo sua história de desenvolvimento a história de um país estruturado inicialmente para produzir bens primários de exportação e, mais tarde, buscando seu desenvolvimento através da industrialização, via processo de substituição de importações: Na realização de seus planos de crescimento, o Brasil tem nas suas relações com o resto do mundo uma das principais condicionantes. No processo de crescimento através da substituição de importações, o governo utilizou-se de um conjunto de pol íticas de cunho protecionista, principalmente na área cambial, e que marcaram o caminho de crescimento com duas características principais: o desequil f́brio no balanço de pagamentos e a inflação (Prebisch, 1964). 0 mercado externo, quer na forma de comprador de nossos produtos e fornecedor das importações de que necessitávamos, quer na forma de fornecedor de empréstimos e de investimentos diretos, representou sempre nossa timitação para alcançar as taxas de crescimento de produção programadas.

Nesta linha de raciocínio, a evolução da dívida externa (entrada de capitais estrangeiros quer na forma de empréstimos quer na forma de investimento diretos) reflete internamerte, em grande parte, a evolução da conjuntura internacional. $O$ entendimento da questão da dívida externa requer, conseqüentemente, um histórico da evolução dessa conjuntura e suas reiações com a economia nacional, de modo a que se possa identificar as fases de desenvolvimento, e a repercussão que cada uma delas trouxe para a econoinia nacional.

O Brasil sempre foi um país de pequena representatividade nos fluxos de comércio internacionais, exceto no que respeita ac café até a década dos 4n. A polftica cafeeira, então, condicionou em grande parte a política cambial; na tentativa de proteger a renda dos cafeicultores eram fixadas regras cambiais que, por várias vêzes, auxiliaram o processo de desenvolvimento via mercado externo (Furtado, 1972). As crises no balanço de pagamentos, asfixiantes em diversas ocasiões, foram atacadas de duas principais maneiras: alterando-se a política cambial de maneira a reverter os déficits agudos, e renegociando a dívida quando outra alternativa não era viável. Desde 1937, nosso ano inicial de análise, a dívida externa brasileira foĺ renegociada em duas ocasiões: 1939 (Missão Oswaldo Aranha) e 1964 (Governo da Revolução). Analisemos a evolução da conjuntura nacional e internacional, para abordar essas duas experiências.

Até 1939, os grandes parceiros comerciais do Brasil eram o Reino Unido e a Alemanha. $O$ comércio era contratado em bases bilaterais, ou 
seja, governo-governo e bancos-governo. Os pagamentos internacionais eram, em sua grande parte, escriturações contábeis sujeitas às regras da época, quando o padrão-ouro já entrara em desuso mas não se havia organizado qualquer alternativa institucional a nível mundial para ele (Bortolani, 1977). Desequilíbrios no balanço de pagamentos dos países desenvolvidos eram corrigidos através ou da transferência de ouro, ou através de políticas internas de cunho monetarista. A regra era que a um déficit deveria corresponder uma diminuição dos meios de pagamento internos, e a um superavit um aumento nos meios de pagamento, de modo a que a taxa de câmbio (paridade entre moedas) se mantivesse estável. Assim, a recessão e a deflacão internas assegurariam a estabilidade das moedas aceitas internacionalmente como meio de pagamento (Gudin, 1965).

A alternativa para corrigir desequilíbrios de balanço de pagamentos desses países seria a variação na taxa de câmbio, fazendo com que esia refletisse o déficit (desvalorização) ou superavit (valorização). Esta medida, porém, repercutiria nos haveres dos parceiros comerciais mais importantes, alterando o valor real dos fluxos de comércio e de pagamento (Soloman, 1977). Ambas as medidas, a política monetária para estabilização interna e a polftica cambial, se fundamentam no pressuposto de que a crise do balanço de pagamentos do país seja temporária; dessa forma, uma recessão interna ou uma desvalorização poderiam sanar a situação de déficit temporário desde que não fossem imediatamente seguidas por atitudes iguais dos parceiros mais importantes.

O crescimento do volume de trocas internacionais na década dos 30 , época em que diversos países europeus voltavam seus esforços produtivos para a preparação da guerra, conduziu a uma reconıposição dos fluxos comerciais internacionais que acentuou o caráter de permanência dos desequiIíbrios do balanço de pagamentos de vários países. Em conseqüência, já a esta época se registravam esforços para encontrar uma nova organização financeira internacional que pudesse evitar as crises de estabilização e contornar a incerteza que cercava o fluxo de pagamentos internacionais. As crises de estabilização eram fruto da aplicação de políticas monetaristas para solucionar os desequilibrios externos - eram custosas e crescentemente ineficientes.

E é justamente no período em que os paises europeus voltavam seus esforços para a guerra que a história registra a decisão do governo de Getúlio Vargas de suspender os pagamentos relativos à dívida pública externa. Em 1937, enfrentando grave crise cambial decorrente da total dependência do mercado londrino, os registros contábeis de nossa dívida e as libras resultantes de nossos superavits para com o Reino Unido ficavam bloqueados no 
centro londrino; a decisão foi, então, de suspender os pagamentos que se quer conhecíamos em seu valor total (Abreu, 1980).

Imediatamente se fizeram sentir as conseqüências da suspensão dos pagamentos, principalmente: (1) a cessação de entrada de novos fluxos de investimento estrangeiro, e (2) a necessidade de renegociar a dívida. Para dar continuidade ao ritmo de atividade interna, tornou-se urgente a necessidade de buscar novos parceiros que pudessem se constituir em mercado para nossos produtos de exportação e, ao mesmo tempo pudessem fornecer os recursos de que necessitava o governo para implementar seu plano de desenvolvimento interno.

O parceiro encontrado, Estados Unidos, não estava diretamente envolvido no esforço de guerra, e foi bastante exigente, condicionando sua parceria à mudança de rumo tanto na política interna (no sentido de maior liberalização nas leis que regulavam a entrada de capitais estrangeiros) quanto da política externa do país em relação a outros países los novos acordos de suprimento e a renegociação da dívida em 1939 passaram a ser dis: cutidos com a presença de representante dos Estados Unidos). Os esforços dispendidos no processo de renegociação de dívida para com o Reino Unido vieram inaugurar a era a hegemonia dos Estados Unidos como parceiro comercial do Brasil. Inicia-se, concomitantemente, a própria era da hegemonia americana nas relações econômicas internacionais - os países, antes e durante a II Guerra Mundial, deixaram de comprar e de vender para seus parceiros habituais, abrindo espaços que foram ocupados pelos Estados Unidos.

Em termos de política econômica interna, em 1939, como parte da solução para renegociação, foi colocado em prática um sistema de taxas múltiplas de câmbio: havia um mercado "livre" (para 70\% cias divisas da exportação), um mercado "oficial" (para 30\% das receitas de exportação, compulsoriamente destinadas ao Banco do Brasil a uma taxa "oficial", sobrevalorizada) e um mercado "livre especial" (para o envio de lucros e dividendos para o exterior, também a uma taxa sobrevalorizada que funcionou como um imposto) (Abreu, 1980). Já à época, portanto, se firmavam as linhas de politica cambial que seria aplicada por longo período, através das carteiras do Banco do Brasil; acentuava-se, no entanto, a necessidade de centralizar institucionalmente as operações de câmbio e a gerência monetária, de modo a fazê-las consistentes (Peláez e Suzigan, 1976).1

1 Neste perfodo a SUMOC (Superintendência da Mooda a do Crédito) detinha as contribuiçóes de controle cambial e monetário, em parte. Somente mais tarde é que veio a ser institucionalizada a geréncia conjunta através da criação do Conselho Monetário Nacional, em 1964, cujo conselho veio a substituir o da SUMOC. A operacionalizaçăo da geréncia monetária a de comércio exterior, no entanto, mesmo hoie năo se encontram centralizadas numa mesma instituiçăo. 
A experiência de renegociação da dívida pública externa, deu-se, portanto, à época em que ainda não se havia firmado o Acordo de Bretton Woods (1945), que viria a alterar as regras do sistema financeiro internacional no sentido de uma maior maleabilidade. Demorada e custosa, a experiência terminou em 1943, quando se restaurou o crédito brasileiro na Europa e os bancos londrinos voltaram a aceitar títulos do governo brasileiro.

Após o término da Guerra, com a criação do Fundo Monetário Internacional (FMI) e do Banco Internacional de Reconstrução e Desenvolvimen. to (BIRD), iniciou-se uma era de crescimento econômico mundial sem precedentes. Novas instituições de fomento e financiamento, novos acordos de tarifas preferenciais, e a divisão do mundo em áreas a serem atendidas por organizações financeiras específicas para cada região, desenharam o perfil econômico do crescimento e das trocas internacionais por mais de três décadas.

Entre 1945 e 1965, os Estados Unidos realizaram superavits contínuos no seu balanço de trocas; esta poupança era transferida para outros países na forma de capitais de empréstimo. Após 1965, entretanto, com os gastos derivados da guerra do Vietnam e enfrentando a concorrência pelos mercados mundiais da Europa reconstruída e do Japão emergente, passaram a se registrar grandes déficits dos Estados Unicos nas trocas com o resto do mundo, tornando cada vez mais difícil manter estáve! o valor de sua moeda. O dólar, dada a crescente importância daquele país no volume de trocas mundial, era a base mais importante de financiamento dos pagamentos internacionais; o ouro, valorado em taxa fixa com o dólar, ainda servia como padrão de referência para os pagamentos, as transferências e a formação das reservas internacionais. Em 1965, porém, já estava esgotado o período áureo de crescimento mundial. Os movimentos recessivos se sucediam nas econcmias industrializadas. Os estoques de ouro não mais asseguravam lastro seguro para o crescente volume de comércio internacional, ficarido cada vez mais difícil manter a paridade dólar-ouro.

As regras de Bretton Woods, afinal, terminaram de cair por terra em 1971, quando o dólar foi desvalorizado e sua conversibilidade em ouro abandonada internamente. A desvalorização do dólar foi decisão acordada entre os dez palses mais importantes do mundo ocidental, sendo acertada uma taxa de desvalorização que não levasse à necessidade dos outros países de desvalorizar em cadeia, para proteger o valor de suas reservas e créditos. As reuniões, à época, demonstraram da urgente necessidade de reorganizar o sistema monetário e financeiro internacional; estudos e tentativas se sucederam desde então, originando inclusive a experiência do DES - Direitos Especiais de Saque, a serem utilizados como uma "moeda internacional" para transferências e formação de reservas (Solomon, 1979). As solu- 
ções encontras para fazer frente aos problemas de desequilíbrio internacional, no entanto, têm sido parciais, na forma de acordos específicos. A questão, em termos de organização internacional ainda permanece irresolvida.

Finalmente, no que respeita ao cenário internacional, a partir dos dois "choques" do petróleo (1973 e 1979), o volume e a direção dos superavits comerciais se alteraram drasticamente a favor dos paises produtores do petróleo. As conseqüências desses choques foram, no curto prazo, a inflação e o desemprego crescentes nos países industrializados; para enfrentar esses dois problemas, as políticas de estabilização emanadas do receituário póskeynesiano passaram a se mostrar crescentemente ineficientes. Constata-se, assim, que os desequil ibrios externos não têm o caráter temporário: são fruto de uma estrutura produtiva e distributiva que, a nível mundial, requerem politicas de prazo longo, a fim de alterar essas mesmas estruturas (Crusius, 1981).

Internamente, a situação econômica brasileira atravessava também crises que se materializavam nos dois problemas principais apontados: desequilíbrio no balanço de pagamentos e inflação. Durante a Guerra, dependemos grandemente dos acordos de suprimento firmados principaimente com os Estados Unidos para escoar nossa produção e obter recursos para impor$\operatorname{tar}^{1}$. Logo após a guerra, beneficiando-se com o crescimento mundial generalizado, essa dependência diminuiu consideravelmente, e o país passou a realizar sua segunda fase de substituição de importações, utilizando-se das grandes reservas acumuladas nos anos precedentes e mantendo uma taxa de câmbio sobrevalorizada (o que incentiva as importações). De 1945 a 1957, as taxas de crescimento foram elevadas; mas ao final desse período nosso principal produto de exportação, o caté, perdeu competitividade no exterior, ao mesmo tempo em que o processo inflacionário se acelerava.

Em 1959 procedeu-se a nova reforma cambial, com 5 taxas diferenciadas de câmbio, numa tentativa de voltar a incentivar as exportações e tornar seletivo o subsídio às importações através de taxas de câmbio sobrevalorizadas. No perfodo 1958/1961, o café não mais sustentava a necessidade de divisas, e o processo de substituição de importações dava sinais de esgotamento. Seguiu-se um período de estagnação com inflação que resultou, em parte, do descontrole das políticas cambial, monetária e fiscal. Em 1961 foi

1 Entre 1941 e 1944, cerca de 60\% de nossas exportaçőes totais foram realizadas em obediência a esses acordos. A pauta de exportaçóes refletia nossa estrutura produtiva à 6́poca: produtos agri: colas (cafe, babaçu, arroz, borracha) e minerais (quartzo, manganés, ferro e outros minerais estratégicos), e nos assegurou a realização de superavits significativos no per (odo. 
feita a tentativa de unificar a taxa de câmbio e torná-la flutuante, para incentivar as exportações e melhorar a situação grave do balanço de pagamentos entretanto seu valor permaneceu fixo durante muito tempo, tornando mais aguda a crise.

A estagnação com inflação se agravou, tornando o problema do balanço de pagamentos o mais premente a ser resolvido. Em 1964 instalou-se o novo governo o qual, contando com o aval dos credores internacionais, optou pela renegociação da dívida externa. Esta segunda experiência de renegociação se deu em condições bastante mais favoráveis que a de 1939, quando a natureza da dívida, o credor mais importante da época, e a direção de cunho fortemente nacionalista do governo dificultavam sobremaneira as negociações.

A exemplo do que acontecia em todo o mundo, na década de 60 acentuou-se o caráter internacional tanto da produção interna quanto das fontes internacionais de financiamento, tendo como moeda hegemônica o dólar americano. No plano interno, a reorganização administrativa permitiu a centralização das decisões maço-econômicas, mērecendo destaque nessa reorganização a criação do Conselho Monetário Internacional, do Banco Central e do Ministério do Planejamento. Os planos de desenvolvimento elaborados pelo governo federal passaram a contar com metas consistentes a serem atingidas através de políticas monetária, fiscal e cambial combinadas.

Entre 1965 e 1973, já contando com os intrumentos de política econômica capazes de fomentar pouparıça e investimento, e dirigi-los para aplicação em setores considerados prioritários dentro dos planos, tivemos a nosso favor uma conjuntura internacional amplamente favorável no que respeita ao mercado externo. ${ }^{1}$ Foi realizada mais uma etapa do processo de industrialização, om que ganhâiam importância os ramos químico e eletro-eletrônico; o parque industrial passou a refletir a estrutura industrial dos países mais desenvolvidos, industrializados. Ao seu exemplo, tornamo-nos mais dependentes de uma fonte de matéria-prima: o petróleo. Os va!nres relativos às trocas internacionais ganharam direção de maior realismo, através da adoção de uma única taxa de câmbio sujeita a mini-desvalorizações. No plano externo, esta fase correspondeu à acelerada ampliação do mercado eurodólar e ao aumento do superavit comercial dos exportadores de petróleo.

A aceleração do mercado de eurodólar, onde fomos buscar capitais de empréstimo, foi possível graças aos déficits comerciais dos Estados Uni-

1 E neste perfodo que deixam de ser renovados os contratos bilaterais com o leste europeu, através dos quais se repetia a situaça para com a Inglaterra (Reino Unido) em 1937: superavits apenas contátbais. 
dos, como apontado anteriormente. Esses déficits foram cobertos com dólares depositados nos bancos europeus, perdendo sua "nacionalidade", ou seja, escapando do controle do governo e do Sistema Federal de Reserva americanos. O mesmo fato já acontecia com as empresas gigan tes de todo o mundo as quais, instalando filiais fora do país-sede, podiam aproveitar os mercados locais e, ao mesmo tempo, fugir das leis e dos impostos de seus países de origem - isto, a transnacionalização da produção.

Já o aumento do superavit dos exportadores de petróleo, entre 1967 e 1973, foi devido aos novos acordos entre os produtores e as empresas exploradoras de petróleo, acordos estes que resultaram numa maior quota para os paises produtores.

Neste período a gerência da política econômica optou pela entrada maciça de capitais estrangeiros, tanto na forma de investimentos quanto na forma de empréstimos. Os acordos bilaterais foram perdendo importância,e as relações financeiras passaram crescentemente a serem feitas entre empresas, com ou sem a interveniência de bancos nacionais. A entrada de empréstimos em moeda pela Lei 4131/62, que regula a entrada e a remessa de capitais estrangeiros, e pela Resolução 63/67 do Banco Central, orientou nossa dívida externa crescente para as mãos dos bancos internacionais - qualquer tentativa de renegociação, a partir de então, representa um esforço de reunião de muitos bancos e de muitos credores.

E nessa situação que se inicia o período a partir do qual o ciclo internacional se torna desfavorável para nós, com as economias em recessão com inflação, sem um sistema monetário internacional que lhes permita enfrentar - problema do balanço de pagamentos de forma adequada, aumentando suas polfticas protecionistas e restritivistas. Entre 1974 e 1978, entretanto, as taxas de juros internacionais ainda não naviam se elevado ao mesmo compassado da inflação internacional - a entrada de capitais de empréstimos foi acelerada no país. A partir de 1979 , os juros internacionais se tornam positivos, em termos reais, e a nossa dívida exierna passa a crescer como uma bola de neve alimentada pelos juros da dívida e levando o país a uma "asfixia cambial", termo bastante adequado para descrever uma situação em que, com um balanço comercial deficitário, se opta por "pagar as contas em dia".

No breve histórico apresentado, buscamos salientar os fatores que determinaram as diversas fases de desenvolvimento interno, tendo como ponto de referência a evolução do sistema financeiro internacional. As crises no balanço de pagamentos brasileiro determinaram, em grande parte, as reformas administrativas $e$ as mudanças de rumo na orientação dos esforços produtivos internos. Considerados esses fatores, podemos dividir a 
análise da evolução da dívida externa brasileira nos períodos a seguir especificados:

(1) 1937/1945: período de renegociação da dívida externa; II Grande Guerra; taxa de câmbio sobrevalorizada (múltipla).

(2) 1947/1954: ciclo internacional favorável; grande aumento nas reservas internacionais; taxa de câmbio múltipla sobrevalorizada.

(3) 1955/1961: esgotamento do processo de substituição de importações; utilização maciça das reservas; reforma cambial com taxas múltiplas de câmbio seletivas para exportação e importação; recrudescimento da inflação.

(4) 1962/1966: estagnação com inflação; período de renegociação da dívida externa; reforma administrativa; taxa única de câmbio sobrevalorizada.

(5) 1967/1973: crèscimento com diminuição de inflação; ciclo internacional favorável; taxa de câmbio única e flutuante.

(6) 1974/1978: reversão do ciclo internacional; déficit no balanço comercial; taxas internacionais de juros reais negativas.

(7) 1979/1981: ciclo internacional desfavorável; recessão com inflação em todo o mundo ocidental; taxas internacionais de juros reais positivas; astixia cambial; aceleraçãu da inflação.

\section{EVOLUÇĀO DAS CONTAS EXTERNAS BRASILEIRAS}

Através da análise das contas do balanço de pagamentos pode-se verificar a evioluçã̃o da formação da dívida externa brasileira. O país se endivida sempre que entra, no país, poupança externa para financiar sua atividade produtiva. Na hipótese de que a poupança interna não seja suficiente para sustentar um ritmo desejado de crescimento interno, faz-se necessária a entrada de poupança externa, quer na forma de capital de risco, quer na forma de capital de empréstimo.

Define-se poupança externa como a entrada líquida de capitais no país e, em condições de ótimo, seu fluxo deve ser igual ao hiato de recursos reais do pais daquele ano. Um fluxo de poupança externa superior ao hiato de recursos reais significa ter havido superavit no balanço de pagamentos e, assim, formam-se reservas internacionais.

O hiato de recursos reāis, entretanto, não possui um conceito que seja unanirnemente adotado pelos analistas. No Brasil, os textos clássicos sobre o tema (Anexo Especial II do Banco Central, 1973, Carvalho, 1974; e Von Doellinger, 1974) apresentam diferentes medidas para o hiato de recursos 
reais, as quais diferem, por sua vez, daquela definida em trabalhos publicados para outros países (por exemplo, Colman e Nixson, 1981).

A idéia da existência de um hiato de recursos reais, em qualquer forma, é a de um excedente (hiato positivo) ou de uma escassez (hiato negativo) de bens e serviços necessários para que a economia trabalhe a um ritmo desejado. Contabilmente, o hiato de recursos reais é definido, no presente artigo, como importações menos exportações mais serviços necessários à colocação dos bens e serviços em solo nacional (fretes, seguros, compra de tecnologia, e diversos (tens de menor valor). Essa medida difere da do saldo do balanço de pagamentos em conta corrente pelo montante do pagamento I ́quido aos fatores de produção - ou seja, aos pagamentos líquidos de juros; lucros e dividendos ${ }^{1}$.

Para chegarmos à análise numérica do hiato de recursos reais, e sua relação com a entrada de poupança externa, vamos examinar os dados contidos nas tabelas 1 (Balanço de Pagamentos do Brasil, decomposto em suas diversas contas), 2 (Taxas Geométricas Médias de Crescimento das Diversas Contas), 3 (Hiato de Recursos Reais e Excedente de Poupança Externa) e 4 (Evoluçăo das Principais Contas Externas, em relativos).

\subsection{Balanço Comercial}

A história das trocas de mercadorias do Brasil com o resto do mundo é uma história de superavits, até os anos 70. Com exceção dos anos de 1952, 1960 e 1962, nossas trocas com o exterior registraram um superavit sistemático até 1970. Entre 1937 e 1970, entretanto, nossa estrutura de produção se alterou substancialmente, tendo o país atravessado um processo de intensa industrialização, baseado na substituição de importações. As trocas em mercadorias com o resto do mundo se consistiram, até então, em fornecedoras de divisas para esse processo.

A análise das pautas de exportação e de importação permite afirmar que: (1) a industrialização sempre foi sustentada pela exportação de bens primários (agr(colas e minerais), no que respeita à óbtenção de divisas para importação; (2) até os anos 70 , a pauta de exportações não se alterou substan-

1 Uma excelente discussáo a respeito do conceito de hiato de recursos reais pode ser éncontrada em Von Doellinger (1974). Analisando os probtemas auméricos ligados a operacionalizacto do con: ceito, o leitor poderá verificar também que há discrepenctas entre dados que eâo publicados pela mesma fonte (Banco Central ou Fundacto Getúlio Vargas). Os números expressos neste artigo di. ferem, por isto, dos números apresentados por outros autores. As fontes, para evitar confuscos, sto citadas a cada ponto. 
cialmente; a diversificação dessa pauta deu-se a partir de 1970, coincidindo com o período em que passaram a ser registrados déficits comerciais; e (3) a pauta de importações se alterou substancialmente no período, refletindo o rumo da industrialização interna; a partir de 1970 essa pauta se tornou cada vez mais rígida, refletindo a dependência do país em relação a insumos, matérias-primas e equipamentos. ${ }^{1}$

O estudo do dinamismo das importações e das exportações, no agregado, pode ser feito através do acompanhamento das taxas médias de crescimento geométrico, por perfodos (Tabela 2). As exportações, em taxas médias anuais, cresceram de maneira tímida até 1967 - até esse ano, a taxa de câmbio foi mantida sobrevalorizada, desincentivando as exportações. Entre 1955 e 1961, as taxas de crescimento médio anual foram negativas. Já a partir de 1967, no entanto, o valor das exportações passou a crescer aceleradamente, com taxas médias de crescimento superiores a $24 \%$ ao ano. Depois do primeiro aumento do preço do petróleo, em 1973, o ritmo de crescimento das exportações diminuiu pouco - o desempenho continua excelente para um mundo que passou a retrair compras e a se proteger em suas trocas comerciais.

As importações, por outro !ado, apresentaram um dinamismo ainda maior que as exportações no período 1967/78. Com as políticas de contencão impostas a partir de 1979, a taxa geométrica de crescimento (média anual), passou a acompanhar a das exportações, permitindo um equilíbrio do balanço comercial em 1981 - ano em que se registra um pequeno superavit.

Até 1979, o aumento dos gastos cum importação de petróleo nãu havia sido compensado por um decréscimo de mesma intensidade dos outros Itens da pauta de importações, numa tentativa de manter o produto nacional crescendo. 0 desequil fbrio estrutural do balanço de pagamentos se acentuou entáo. As exportações ainda eram basicamente de produtos primários lem volume não significativo no comércio internacional e, portanto, não comandando seus preços; e de baixa elasticidade-renda). As importações, por sua vez, permaneciam sendo de produtos vitais para a manutenção do ritmo interno de atividade (alta elasticidade-renda, com preços também determinados

1 A evoluçáo de composiçăo e do destino das exportacós deu-se na direçáo de uma diversificaçăo maior a partir de 1970. Em 1982, $50 \%$ das exportacos correspondern a manufaturados, $40 \%$ das vondas se destinam a paises mer:s desenvolvidos (Informativo do BCB, Ano 2, n. 24, j:tho/82) no 1? somestro. 
fora de pais e refletindo a crescente inflação dos pa(ses industrializados) (Carvalho, 1974; Munhoz, 1981).

As dificuldades que os números para o último período (1979/81) registram refletem as dificuldades de colocação dos produtos brasileiros no exterior, com queda de preço das "commoditties", o aumento do protecionismo norte-americano impondo quotas e impostos sobre tradicionais produtos exportados pelo Brasil àquele mercado. A relação de troca com o resto do mundo volta, no período, a ser desfavorável ao país.'

\subsection{Balanço de Serviços}

A história das trocas de serviços do Brasil com o resto do mundo, ao contrário das trocas de mercadorias, é uma história de déficits. Da ampla gama de serviços que compõem essa conta do balanço, os mais importantes estão descritos pelos dados das Tabelas 1 e 2, e sua evolução através de relativos está representada no Gráfico 1.

O ftem que apresentou a evolução menos intensa foi o de serviços de não-fatores (fretes, seguros e viagens internacionais). 0 déficit histórico dessa conta diminuiu, principalmente devido ao desenvolvimento dos serviços brasileiros em seguros e fretes. A conta de serviço de fatores flucros, juros e dividendos), em contraste, apresentou o maior crescimento dentre todas as contas do balanço de pagamentos brasileiro. A evolução do subítem juros tem resultado num aumento impressionante da conta serviços: o saldo Íquido dos juros cresceram a uma taxa média anual (geométrica) de $50 \%$ no período $1978 / 81$, e de $43 \%$ no período $1973 / 81$ (ver Tabela 2 ).

A conta serviços é de vital importânciá para a discussão da relação entre hiato de recursos e poupança externa. A dívida externa, como se demonstrará adiante, aumentou mais do que seria necessario no perfodo 1967/1973 - a contratação da dívida se torna necessária a partir da existência de um hiato de recursos reais que necessita ser financiado por poupança externa. Definido a partir do saldo do balanço de mercadorias mais o saldo do balanço de serviços (exclusive serviços de facores), os números que indicam o hiato de recursos se encontram discriminados na Tabela 3.

Dado que a conta serviços tem sido sistematicamente deficitária no Brasil ao longc de sua história, ganha importância o que acontece com o

1 Para a discussáo a cerca da evoluçáo da relaça de trocas do Brasil, ver Prebisch (1964) e Gonçalves (1982). A evoluço do preço das "commoditties" e sua relaçáo com o balanço do pagamentos apresentam-se na revista Confuntura Econômica , junho - julho/82. 
balanço comercial, quando pretendemos nos independizar da poupança externa para financiar nosso desenvolvimento interno. Os dados da Tabela 3 , entretanto, mostram que apenas no período 1962/1966 o hiato de recursos foi positivo - em decorrência do processo de renegociação da dívida e do superavit comercial entre 1963 e 1966. Neste período, então, não teria sido necessária a entrada de poupança externa na forma de empréstimos - o excedente de exportações teria financiado nossas necessidades de divisas.

Para os outros períodos discriminados na Tabela, entretanto, o hiato de recursos foi negativo, acelerou-se entre 1974 e 1978, e foi sistematicamente inferior ao saldo do balanço em conta-corrente (por definição, dado que a conta de serviços de fatores tem sido deficitária). A diferença entre o hiato e o saldo em conta-corrente tem se ampliado acentuadamente, devido justamente à evolução da conta juros.

Dado o hiato de recursos reais, de quanto necessita o país de poupança externa para realizar sua atividade produtiva ao ritmo desejado? Ora, este não é um problema estático, do airo - já que além de financiar a produção deste ano, na forma de mercadorias, fretes, tecnologia. o país tem que pagar ao investimento estrangeiro instalado no passado (remunerá-lo através de lucros e dividendos enviados ao exterior) e pagar aos empréstimos contratados também no passado (na forma de amortizações e juros). A relação entre poupança externa e hiato de recursos envolve, por isto, a análise da conta de capitais do balanço de pagamentos.

\subsection{Balanço de Capitais}

A dívida externa se forma a partir da entrada de capitais de empréstimo e capitais de risco no país. A poupança externa é indicada pelo saldo do balanço de capitais (autônomos mais compensatórios), e a variação anual desta conta define o aumento da dívida externa. Assim, à entrada de capitais externos corresponde o financiamento da produção interna, por um lado. Por outro lado, corresponde a um aumento no endividamento, que deverá ser pago nos prazos e condições contratados.

Quando o hiato de recursos é justamente coberto pela entrada de poupança externa na forma de capitais de empréstimo e de risco, há equilíbrio no balanço de pagamentos. Quando a entrada de capitais externos supera o hiato de recursos reais, há um superavit, que permite acumular divisas (reservas internacionais). Caso contrário, o balanço de pagamentos entra em déficit, que tem que ser coberto ou por capitais compensatórios ou pela utilização das reservas. 
Os dados apresentados na Tabela 3 indicam que a entrada de poupança externa foi superior ao hiato de recursos reais em todo o período compreendido entre 1947 e 1981, superando inclusive o saldo do balan. ço em conta-corrente no período 1967/1978. Independentemente da composição desses capitais externos, o que se conclui é que, neste período, o país se endividou sem necessidade aparente - foi nesse perfodo que se deu a maciça entrada de recursos externos na forma de investimentos diretos e empréstimos em moeda.

A opção de crescer com tal intensidade de endividamento latravés da realização de excedentes volumosos de poupança externa, como indicado na Tabela 3) tem sido responsabilizada pela atual situação de asfixia cambial, e sua aceitação já à época era no mínimo controvertida: já que poupança externa é endividamento, qual a razão de se incentivar a entrada no país de um excedente de poupança como foi feito a partir de 1967?

A tomada de empréstimos em moeda, após 1967, veio acompanhada de uma entrada volumosa de investimentos sstrangeiros. O Gráfico 1 ilustra uma relação: tomando-se 1968 como base $(=100)$, verifica-se que todos os ítens do balanço de capitais (investimentos líquidos diretos, empréstimos e financiamentos e amortizações) cresceram relativamente mais que os outros ítens úo balanço de pagamentos, exceto juros - estes são, na verdade, a remuneração, no presente, aos empréstimos contratados no passado e, portanto, um ftem de "capital". Os investimentos estrangeiros, portanto, só tiveram seu crescimento ul trapassado pelo crescimento dos juros. A indução à tomada de empréstimos após 1967 é justificadá pelas autoridades como uma maneira barata de formar reservas internacionais num período em que o sistema financeiro internacional se encontrava conturbado: a taxa de juros real dos empréstimos em moeda ara negativa. Assim, os bancos estrangeiros estariam subsidiando a formação de nossas reservas (Kincaid, 1981). A indução ao investimento estrangeiro, por outro lado, é justificada pela meta de crescer aceleradamente, no padrão das economias industrializadas possuidoras da tecnologia e da escala de produção necessárias para dar continuidade ao modelo exportador.

$O$ aumento do endividamento externo veio trazer suas primeiras conseqüências quando o mundo se reorganizava após o primeiro "choque" do petróleo: a entrada de capitais de risco se desacelerou, e os empréstimos em moeda passaram a se tornar caros, em termos reais. A taxa média de crescimento dos investimentos líquidos estrangeiros passou de $52 \%$ a.a. (1967) 73) para quase $12 \%$ a.a. $\{1973 / 81$ ). Os empréstimos e financiamentos, para os mesmos perfodos, baixaram de uma taxa de cerca de $43 \%$ a.a. para quase $17 \%$ a.a. O excedente de poupança externa acumulada entre 1974 e 1981 
tornou-se, por isto, negativo: em apenas três anos (1979/1981) os déficits do balanço de pagamentos superaram ao excedente de poupança acumulado nos anos precedentes, apesar do bom desempenho das exportações durante todo o período.

Convém salientar que o excedente de poupança relativo à diferença entre o saldo de poupança externa e o saldo do hiato de recursòs reais foi sempre positivo (ver Tabela 3). Isto representa que durante todo o período 1947/1981, utilizou-se de poupança externa não apenas para financiar as necessidades de recursos para a produção, e sim para o consumo e para o pagamento das dívidas acumuladas no passado (remuneração aos empréstimos e ao capital fixo realizados no passado). As conseqüências do endividamento feito para financiar além do hiato de recursos reais, no plano interno, são, principalmente: (1) a poupança externa substituiu a poupança interna, e não complementou-a (Carvalho, 1974i; e (2) uma forte correlação entre dívida externa e dívida interna (ORTN e LTN) mostia que, ao transformar os empréstimos externos em cruzeiros e esterilizando-os na forma de títulos federais, o governo utilizou-os internamente para financiar seus gastos e controlar a oferta monetária.

Em relação a este segundo ponto, os efeitos da correlação se fazem sentir fortemente em 1982: se, por um lado, a política de mercádo aberto permite ao governo financiar suas despesas sem emitir moeda, por outro lado inflaciona a economia através da elevação dos juros e dos próprios gastos federais. Quando o excedente de poupança externa passa a diminuir, e mesmo se tomar negativo como nos anos recentes, diminuem os graus de liberdade da política monetária como política de estabilização interna, num modelo que continua a se fazer sustentar pelo endividamento. Qualquer tentativa de aumentar o ritmo de atividade tem que ser feita através da política fiscai, e/ou através do aumento dos juros para atrair capitais externos tornando-se altamente inflacionária. E, o que é pior, as tentativas de pagar as contas em dia restringindo importações, incentivando exportações e atraindo capitais de empréstimo numa conjuntura internacional em que os parceiros comerciais mais importantes estão atuando de forma idêntica, resultam internamente em recessão com mais inflação. Completando o círculo vicioso do crescimento com endividamento, acentua-se a asfixia cambial. Os indicadores desta situação são discutidos a seguir.

\section{MEDIDA E INDICADORES DO ENDIVIDAMENTO EXTERNO}

Nas Tabelas 5, 6 e 7 estão discriminados alguns indicadores da situação de endividamento recente (pós-68). Os Gráficos 2, 3 e 4 ilustram 
esses indicadores. Pela Tabela 7, observamos a al teração na composição da dívida externa brasileira: os empréstimos compensatórios, ainda importantes em 1968 (17,4\% da dívida total), tornam-se praticamente nulos a partir de 1975. Os empréstimos oficiais também perdem importância relativa para os empréstimos em moeda - estes, que representavam $28,6 \%$ da entrada de capitais em 1968, passam a representar mais de $73 \%$ deste total em 1981! Com isto, $73 \%$ de nossa dívida externa passa a ser recontratada periodicamente, no ritmo de variação dos juros internacionais devido à cláusula presente em todos os contratos firmados através de bancos: a cláusula da taxa de juros variável. Os empréstimos para projetos de desenvolvimento, firmados com agências internacionais a juros fixos e prazos mais longos, se tomam relativamente menos importantes nesse periodo entre 1968 e 1981, aumentando nossa dependência em relação à política de juros principalmente dos Estados Unidos (empenhados em trazer de voltā ao país os eurodólares). Mudando a composição da dívida externa, tende a mudar também o perfil dessa dívida (Tabela 6). Quando o fluxo de empréstimos em moeda começou a se acelerar e ganhar vulto na composição da dívida, a maior pressão sobre os pagamentos estava no 1. ano de vencimento; após 1973, reiniciaramse os esforços para distribuir melhor o serviço da dívida (amortizações mais juros), resultando num aumento da parcela dos juros sobre a de amortizações. Esse processo de "rolar" a dívida tem nos acompanhado desde então. O prazo médio total de vencimentos dos empréstimos, conforme mostra a Tabela 6, diminuiu, demonstrando a pressão sobre os prazos de vencimento que representam os empréstimos em moeda.

Os coeficientes usualmente utilizados para indicar a posição de sustentação dos pagamentos internacionais são: (1) o coeficiente de proteção percentagem que se poderia deduzir no fluxo de empréstimos de um ano sem precisar aumentar o hiato de recursos paı a atender ao serviço da dívida; (2) o coeficiente de capacidade de pagamento, indicado pelo quociente (dívida externa líquida / exportações), onde a dívida externa líquida representa a dívida externa total mienos reservas internacionais; e (3) o coeficiente de vulnerabilidade - percentagem do hiato de recursos positivo necessário para pagar o serviço da dívida na hipótese de não entrar qualquer novo valor em empréstimos e financiamentos (este úl timo coeficientẹ tem sua validade estática muito discutida - ver Anexo Especial II, 1973).

Os valores dos coeficientes estão discriminados na Tabela 5 . 0 coeficiente de proteção baixa de $63 \%$, em 1974, para 1\%, em 1981 - dependemos totalmente da entrada de empréstimos novos para pagar o senviço da dívida. $O$ segundo coeficiente que nos interessa discutir é o coeficiente de capacidade de pagamento (coluna 9 da Tabela 5), que indica em quantos 
anos pagarfamos toda a dívida externa se exportássemos o valor daquele ano. Tendo uma evolução mais regular que o coeficiente de vulnerabilidade, o coeficiente mostra que nossa capacidade de pagamento da divida através das exportações tem diminuído lo número de anos de exportação necessários para pagar a dívida tem aumentado). O grande acúmulc de reservas internacionais, somado ao volume de exportações de 1973, permitiria que pagássemos a dívida em um ano. Contrastando, em 1981 seria necessário esgotarmos nossas reservas e sustentarmos 2, 3 anos de exportação como a do ano para pagarmos os credores externos.

A evolução dos indicadores mostra que, inequivocamente, estamos numa situação pior em 1981 que estávamos em 1973, no que respeita à possibilidade de pagar as contas externas em dia. ${ }^{1}$

Os Gráficos 2, 3 e 4 ilustram a evolução das contas relativas ao serviço da dívida. Por eles, fica comprovado visualmente o exagerado crescimento da conta juros: em 1981 pagamos 50 vezes mais juros que em 1968, enquanto que as exportações cresceram menos do que 13 vezes no mesmo período. O exame cuidadoso da Tabela 5 permitirá ao leitor examinar a evolução dos itens de medida e dos indicadores da dívida externa.

\section{AS RESTRIÇÓES PARA CONTINUAR "PAGANDO AS CONTAS EM DIA"}

Identificados alguns elementos determinantes da dívida externa brasileira, cabe apontar a margem de manobra com que contam as autoridades pala dar continuidade à opção de condicionar o ritmo de atividade interna, bem como a direção dos esforços pratutivos, ao pagamento das contas externas. As restrições que o quadro econômico internacional encontra são bastante diferentes daquelas que as outras crises cambiais pelas quais atravessamos nos trouxeram em outras épocas, citadas anteriormente. O quadro recessivo mundial não mostra sinais de cansaço, o que tem levado à estagnação de nossas exportações; a tomada de atitudes protecionistas, principalmente, por parte do maior parceiro individual, Estados Unidos, agravam a situação para - Brasil. O preço de algumas de nossas exportações mais importantes enfrentam uma acentuada baixa, enquanto que o preço das importações refletem a inflação internacional e a incerteza na continuidade do suprimento de produtos tão importantes quanto o petróleo. Os juros internacionais, assim co-

1 Com a rápida diminuição das reservas a a estagnaçăo do valor das exportaçóes em 1982, o coeficiente (3) tem sofrido aumento significativo. 
mo o desemprego, mostram-se resistentes à baixa. Mais de $60 \%$ da dívida ex terna dívida pública. Juntando-se a outros países que já deram início ao processo de negociação, a Argentina aumenta o número dos inadimplentes internacionais.

A situação financeira internacional é hoje, em seu conturbado desempenho, o resultado dos problemas estruturais por que passa o mundo industrializado - como as economias periféricas em seus primeiros estágios de industrialização, os países desenvolvidos têm se voltado para a aplicação de políticas protecionistas, para resolver seus sérios problemas de balanço de pagamentos. Até o presente países como o Brasil (e principalmente o Brasil, por arcar cam os maiores "spreads" mundiais e ser o maior devedor individuai, acompanhado de perto pelo México) tiveram condições de financiar as tentativas de estabilização dos países industrializados, quando estes se viram premidos a pagar o petrólèo mais caro (Tabela 8). Realizando déficits comerciais, e financiando seus empréstimos com os mais altos "spreads" mundiais, o Brasil tem financiado o capital financeiro internacional, que é assim cedido a outros países a taxas menores ou mesmo negativas (casos recentes de renegociação); tem, também, permitido a outros países realizar superavits comerciais equilibradores, aceitando os preços que se formam fora de suas fronteiras para seus próprios produtos, destinados ao Mercado Cómum Europeu e Estados Unidos (ver Tabela 8).

- A possibilidade de continuar sustentando essa situação, entretanto, toma-se cada vez mais difícil. As condicionantes externas são, conforme apontado anteriormente, a viabilidade de realizar um saldo positivo no balanço comercial; uma queda na taxa de juros internacional que diminua a pressão da "bola de neve" da dívida; e a manutenção da confiança do setor de bancos internacionais na continuidade da linha de política econômica adotada até o momento, que é de convivência e cooperação permanente com esse mesmo setor. Apenas essa última condicionante depende da ação do governo brasileiro, através de suas opções de política econômica.

As condicionantes internas, por sua vez, são a existência de projetos rentáveis para atrair os empréstimos exiernos e os investimentos estrangeiros diretos, dificilmente prováveis numa situação de contínua recessão; e a própria inflação - que representa a capacidade do governo de atender a reivindicações das diversas classes produtivas, inclusive a do próprio setor estatal, através de endividamento interno, sem perder o controle sobre os índices inflacionários.

A alternativa à opção de pagar as contas em dia, através de políticas recessivas e inflacionárias, é uma nova renegociação da dívida externa. Esta alternativa poderia ser forçada por uma alteração nos limites das condicionan- 
tes listadas acima. As conseqüências de uma outra experiência de renegociação, atualmente, diferem em muito das experiências de 1939 a 1964: a natureza da dívida agora é de empréstimos em moeda, contratados com bancose não mais com governos, e a situação de inadimplência internacional é crescente. Os custos dessa al ternativa, entretanto, deverão ser necessariamente ou maiores concessões ao çapital internacional, ou sacrifícios maiores e mais prolongados à economia interna -- conforme se opte por alterar a direção do modelo brasileiro de desenvolvimento para uma economia mais aberta ou menos aberta ao mercado externo. A adequação da produção para o mercado interno, no segundo caso, requer uma substancial transformação nas estruturas produtiva, distributiva e financeira - e isto nã́o se fará sem uma recomposição do atual equilíbrio social.

A margem de sustentação da política externa atualmente em vigor no campo econômico tem diminuído. A tomada de posição a respeito do ataque ao problema da dívida externa, por sua vez, é uma questão de definição a respeito do modelo globá de desenvolvimento a ser implementado - mais ou menos voltado para o mercado externo. Uma definição política, portanto.

\section{BIBLIOGRAFIA}

1. ABREU, Marcelo de Paiva:"A Economia Brasileira e a Segunda Guerra Mundial: o Setor Externo", em Economia Brasileira: Uma Visão História, Paulo Neuhaus (Coord.), Editora Campus, 1980.

2. BORTOLANI, Sérgio: A Evolução do Sistema Monetário Internacional, Coleção Chaves da Economia, Edições 70, 1977.

3. COLMAî,; D. e NIXSON, F.: Desenvolvimento Econômico: uma Perspectiva Moderna, Editora Campus, 1981.

4. CRUSIUS, Y.R.: "A (Hậ?) Escolha entre Inflação e Desemprego", Revista Perspectiva Econômica, vol. XLXI, n. 34, 1981.

5. "Developments in and Prospects for the External Debt of the Developing Countries", World Bank Staff Working Paper n. 488, August 1981. 6. FISHLOW, Albert: "A Divida Externa Latino-americana: um Caso de Desenvolvimento com Incerteza", Revista Pesquisa e Planejamento Econômico, vol. $11, n^{\mathrm{O}}$. 2, agosto 1981.

7. FURTADO, Celso: Formação Econômica do Brasil, Editora Nacional, 1972.

8. GÓNÇALVES, A.C.D.: "O Problema Brasileiro de Balanço de Pagamentos vol. 34, n. 4 , out/dez 1980. 
9. GONÇALVES, R. e BARROS, A.C.: "Tendências dos termos de troca: a Tese de Prebisch e a Economia Brasileira - 1950/1979", Revista Pesquisa e Planejamento Econômico, vol. 12, no 1, abril, 1982. 10. GUDIN, E.: Princípios de Economia Monetária, Editora Agir, 1965. 11. KINCAID, G.R.: "Inflação e Dívida Externa dos Países em Desenvolvimento", Finanças \& Desenvolvimento, vol. 1, n. 2, dez. 81.

12. LUZ, J.A. e MALAN, P.S.: "O Desequilíbrio do Balanço de Pagamentos: Retrospecto e Perspectivas", Brasil: Dilemas de Política Econômica, Dion ísio Dias Carneiro (Coord.), Editora Campus, 1977.

13. MANOLESCU, F.M.: "Brazilian Extern Debt (1968 - 1976)", Anais do VI Encontro Nacional de Economia - ANPEC, 1978.

14. MUNHOZ, D.G.: "Os Desequilíbrios Externos da Economia Brasileira", Revista de Economia Política, vol. 1, no 4, out-dez 1981.

15. CARVALHO, J.E.P.: "Financiamento Externo e Crescimento Econômico no Brasil: 1966/73", Relatório de Pesquisa IPEA, n. 27, 1974. 16. PREBISCH, R.: Dinâmica c's Desenvolvimento Econômico Latino-Americano, Editora Fundo de Cultura, 1964.

17. Relatório do Banco Central do Brasil, Anexo Especial II, 1973.

18. SCHAFER, H.B.: "Dívida Externa Brasileira: Problemas e Perspectivas", Revista de Economia Politica, vol. 1, no 4, out./dez 1981.

19. SILVA, A.: "Inflação: Reflexões à Margem da Experiência Brasileira", Revista de Economia Política, vol. 1, n. 3, jul/set 1981.

20. SOLOMON, R.: O Sistema Monetário Internacional - 1945-1976, Zahar Editores, 1979.

21. SUZIGAN, W. e PELAEZ, C.M.: "História Monetária do Brasil: Análise da Política, Comportamento e Instituições Monetárias", Série Monografia IPEA, n. 23, 1976.

22. VON DOELLINGER, C., FARIA, H.B.C. e CAVALCANTI, L.C.: "A Política de Comércio Exterior e seus Efeitos: 1967/73", Relatórios de Pesquisa iPEA, n? 22, 1974. 


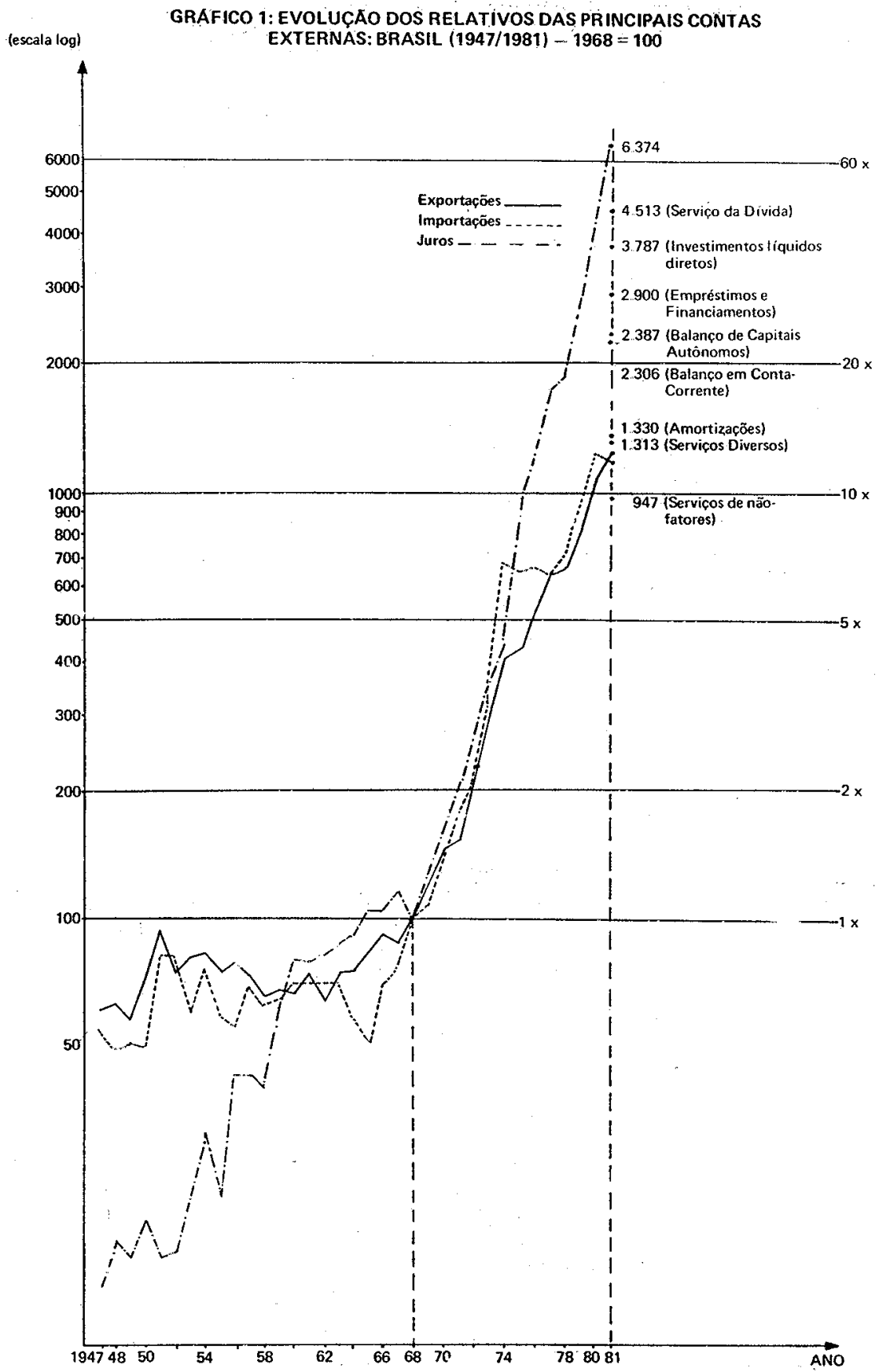


GRAFICO 2: ENDIVIDAMENTO EXTERNO BRASILEIRO (1969/1981) --

COEFICIENTE COEFICIENTE (DIVIDA EXTERNA LIOUIDA / EXPORTACOES)

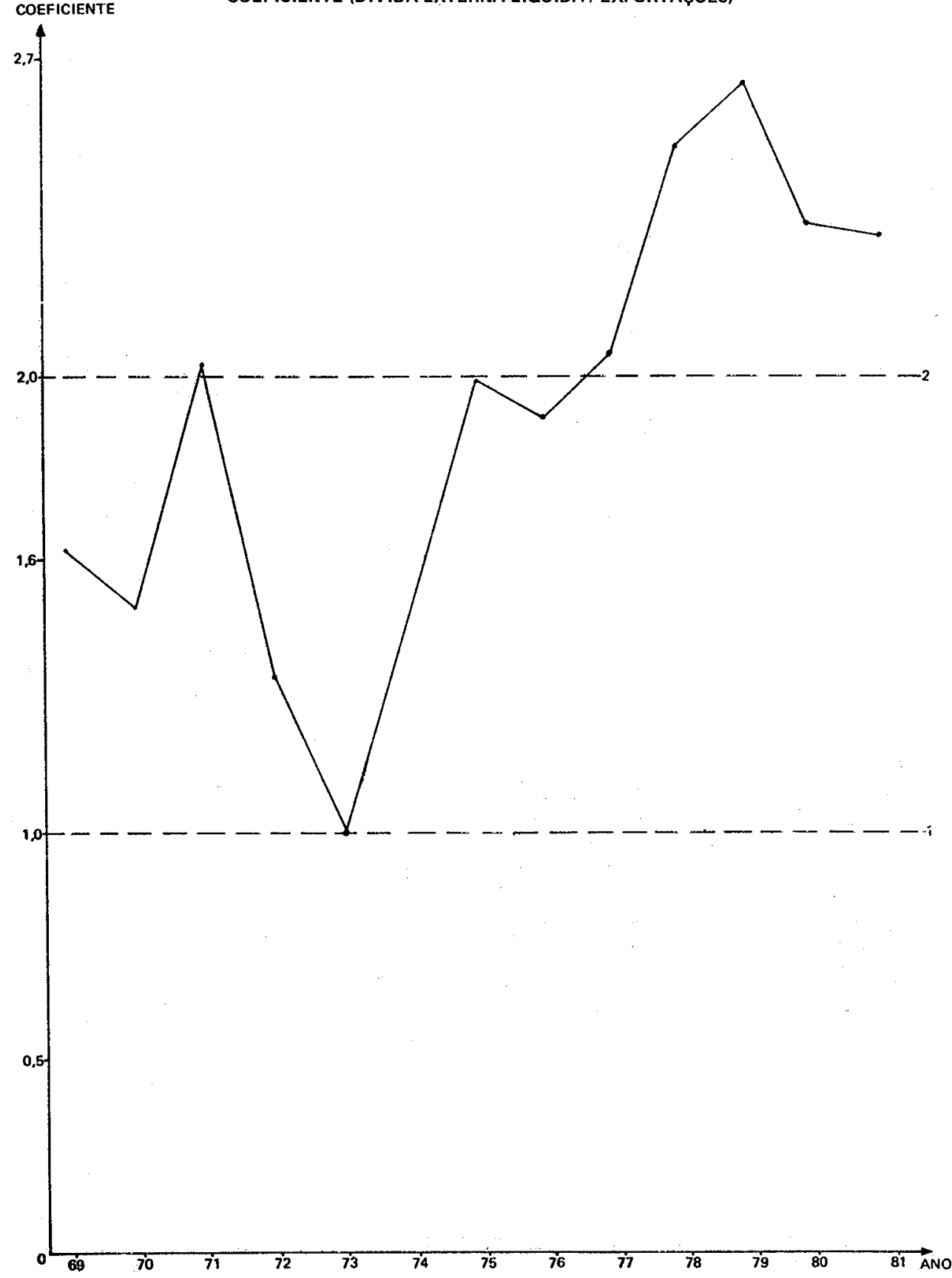

44 
GRAFICO 3: ENDIVIDAMENTO EXTERNO BRASILEIRO (1969/81) --

EVOLUÇAO DO SERVIÇO DA DIVIDA $(1969=100)$

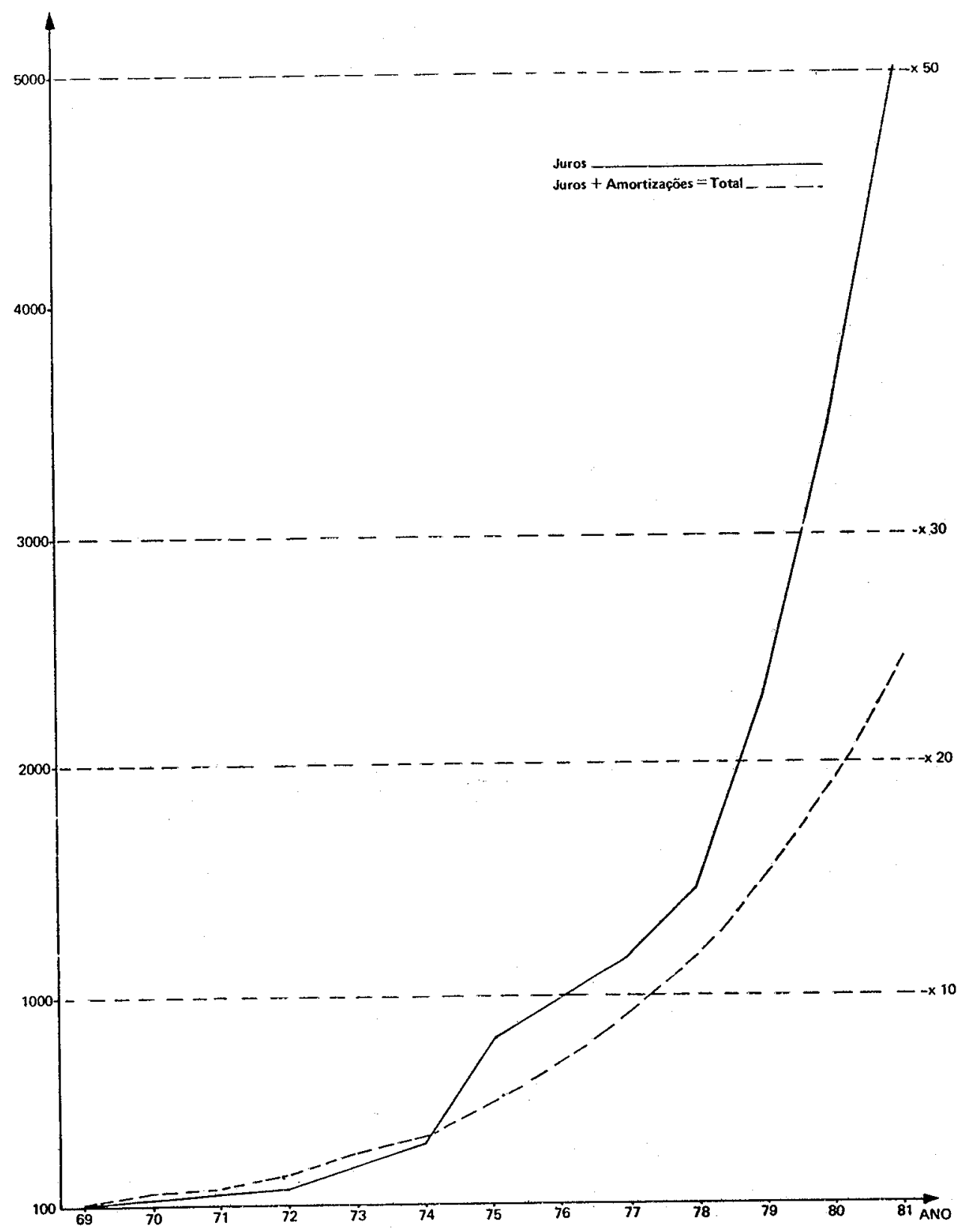


EVOLUÇÄO DA DIVIDA $(1969=100)$

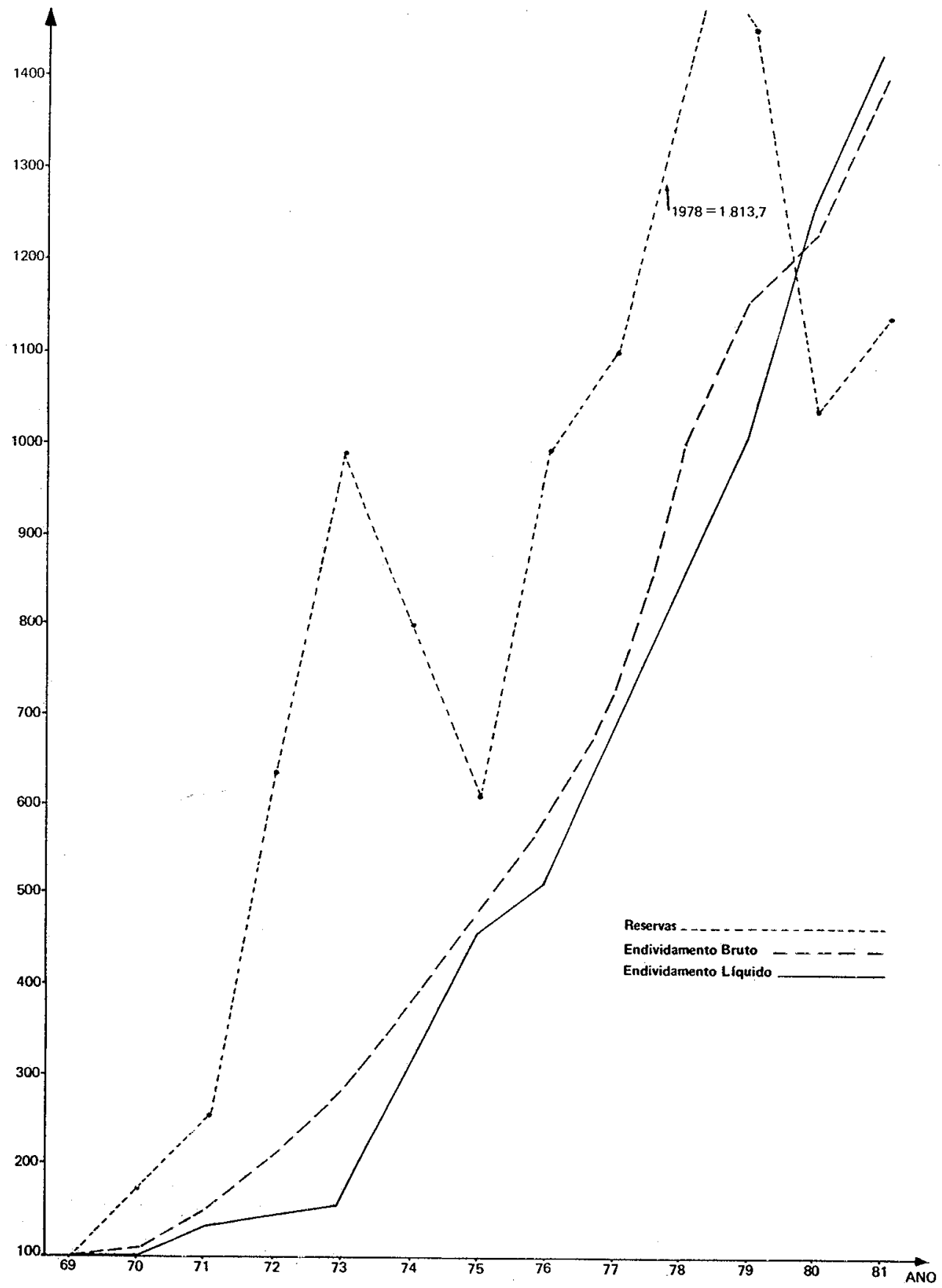




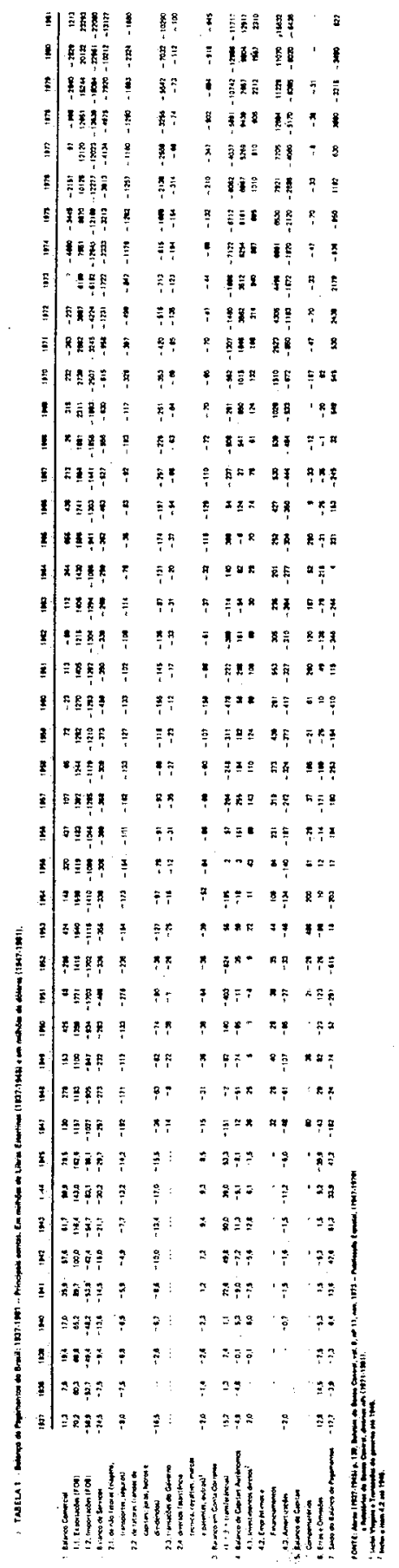




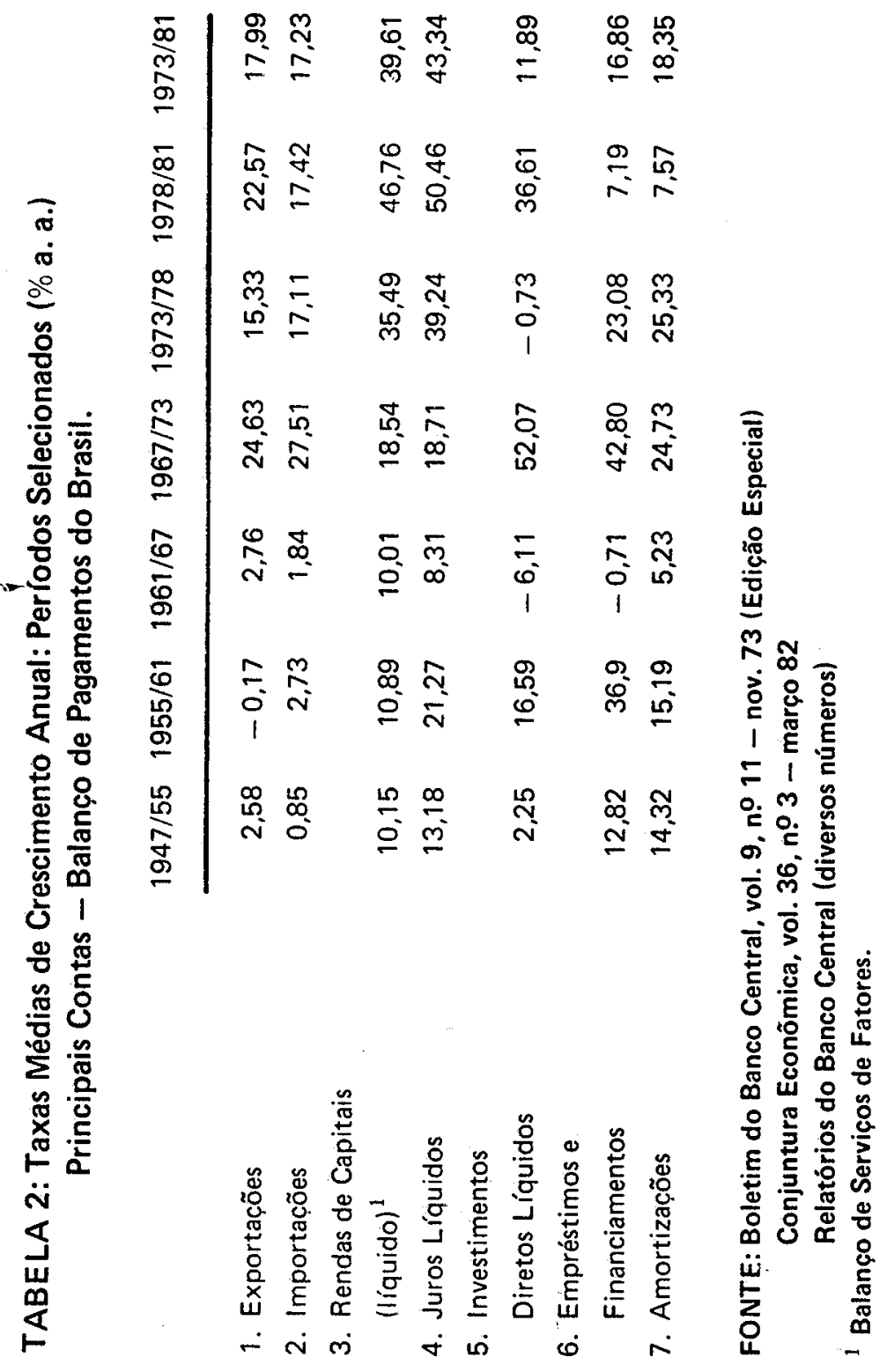




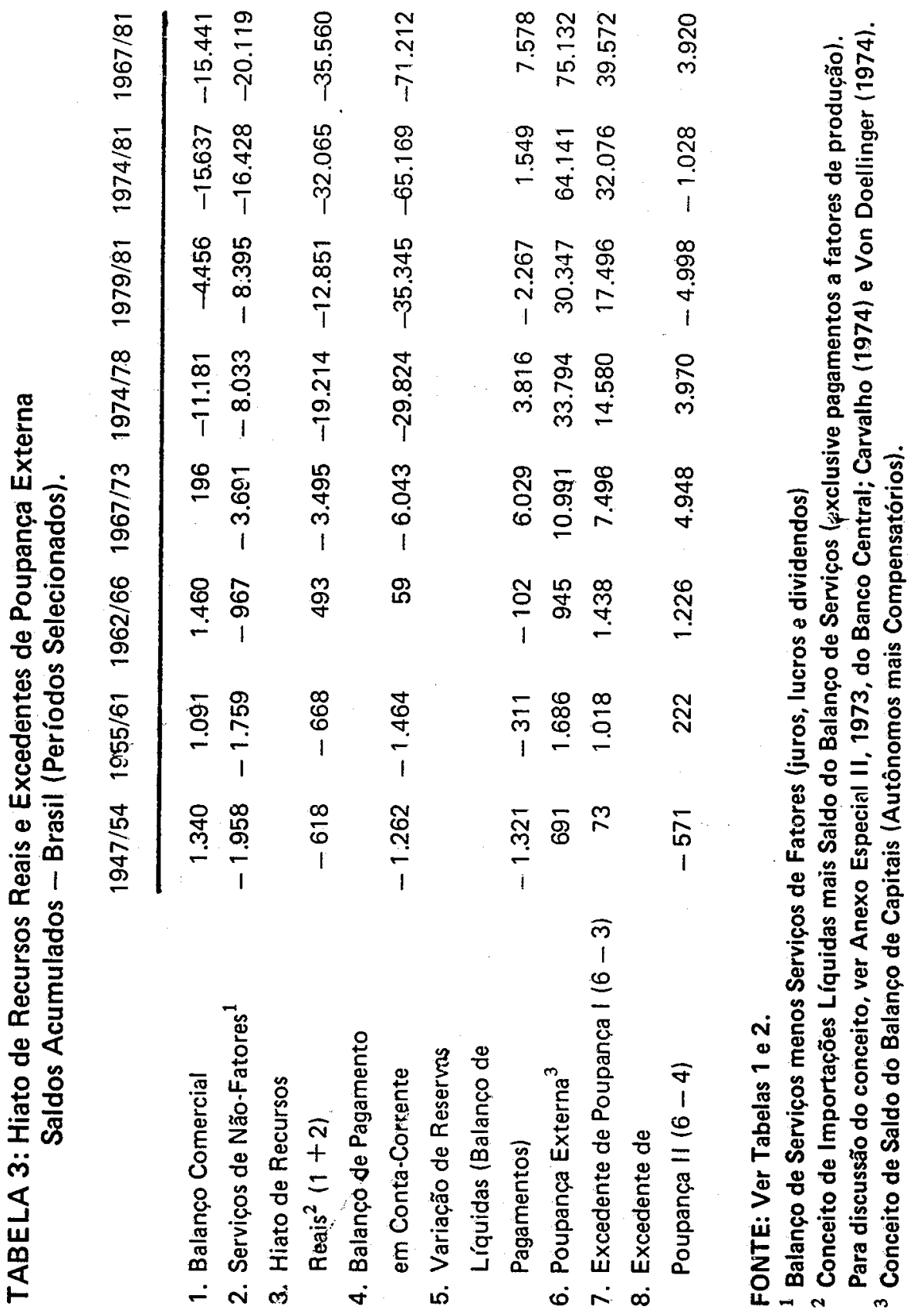


N

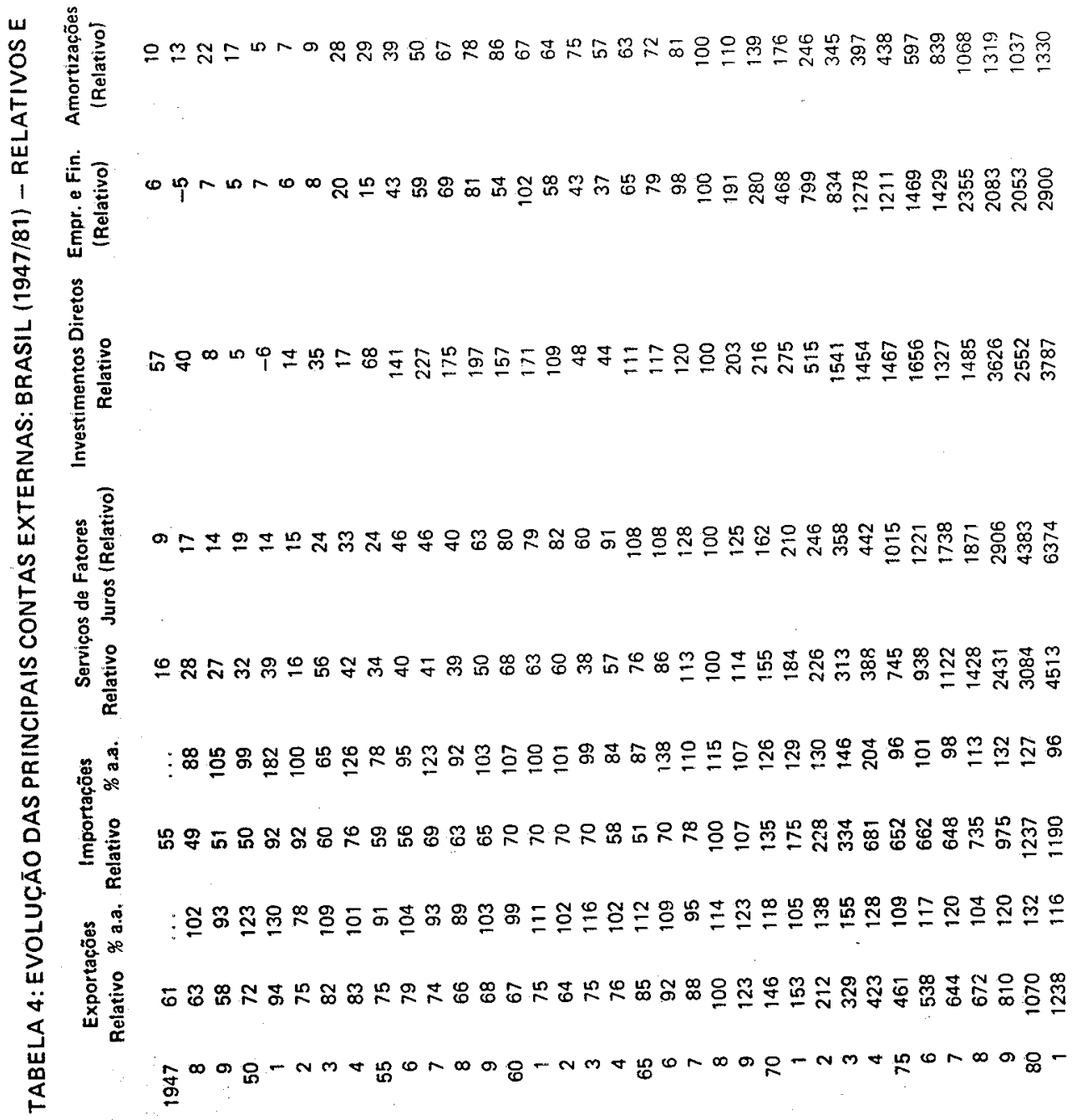




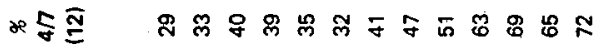

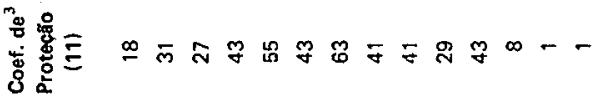

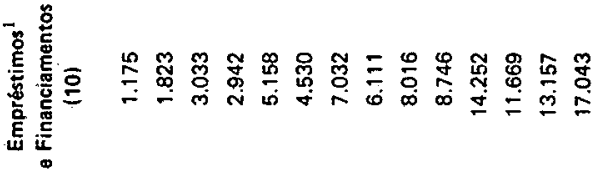

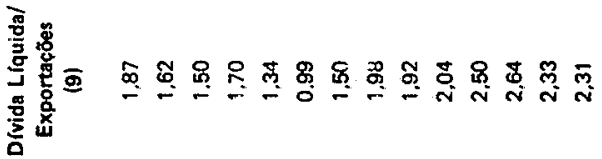

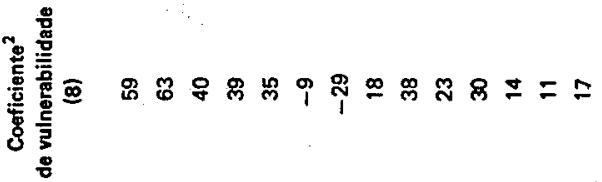

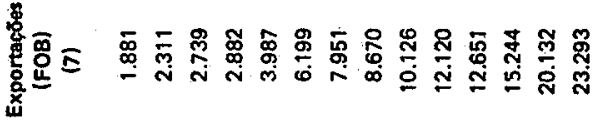

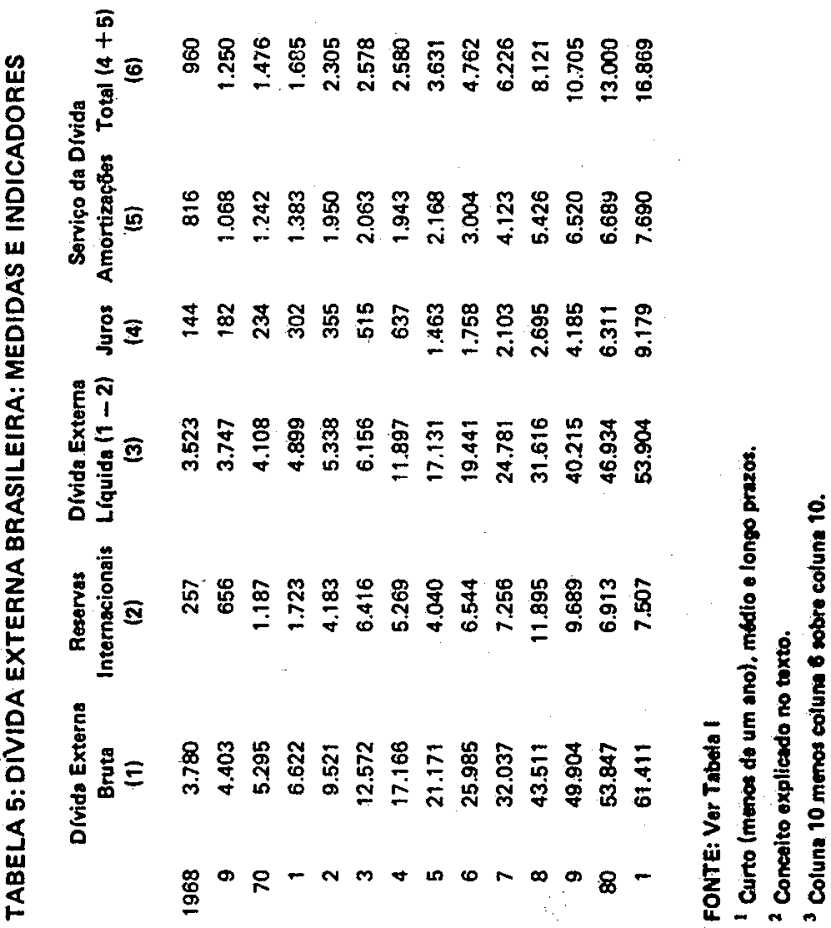




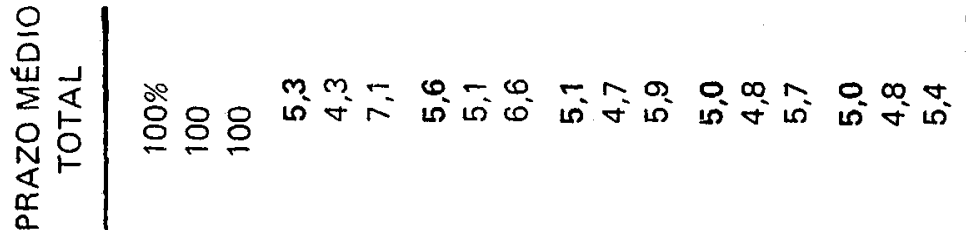

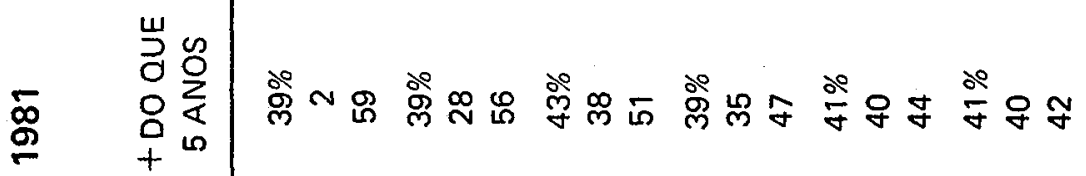

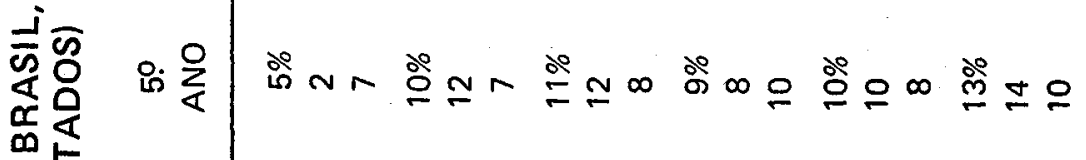

$$
\begin{aligned}
& \text { 发贾 }
\end{aligned}
$$

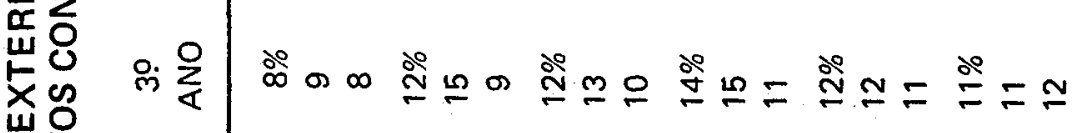

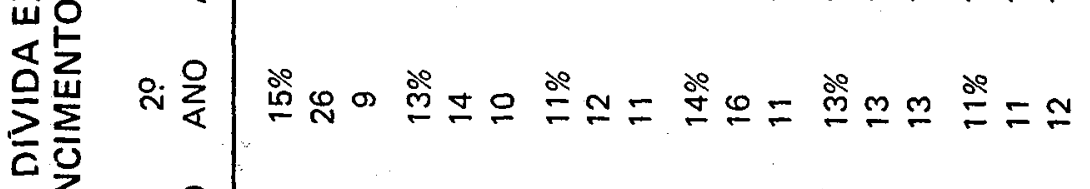

$$
\begin{aligned}
& \text { 造出 윴 }
\end{aligned}
$$

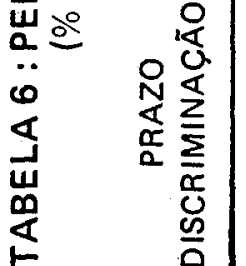

$$
\begin{aligned}
& \text { 웅 }
\end{aligned}
$$

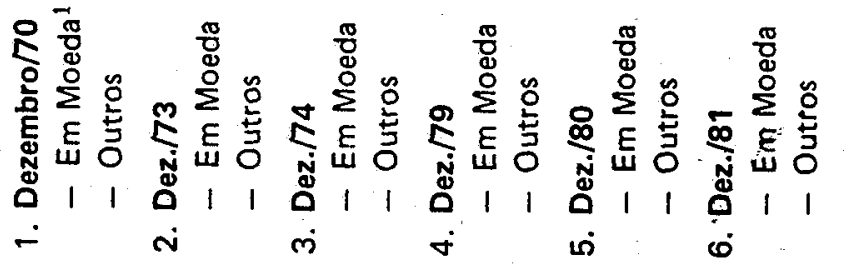

$$
\begin{aligned}
& \text { i }
\end{aligned}
$$

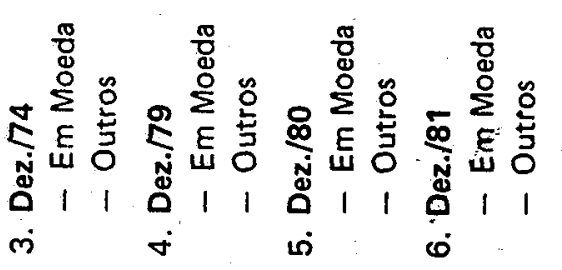

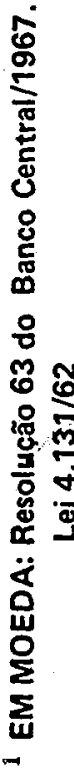




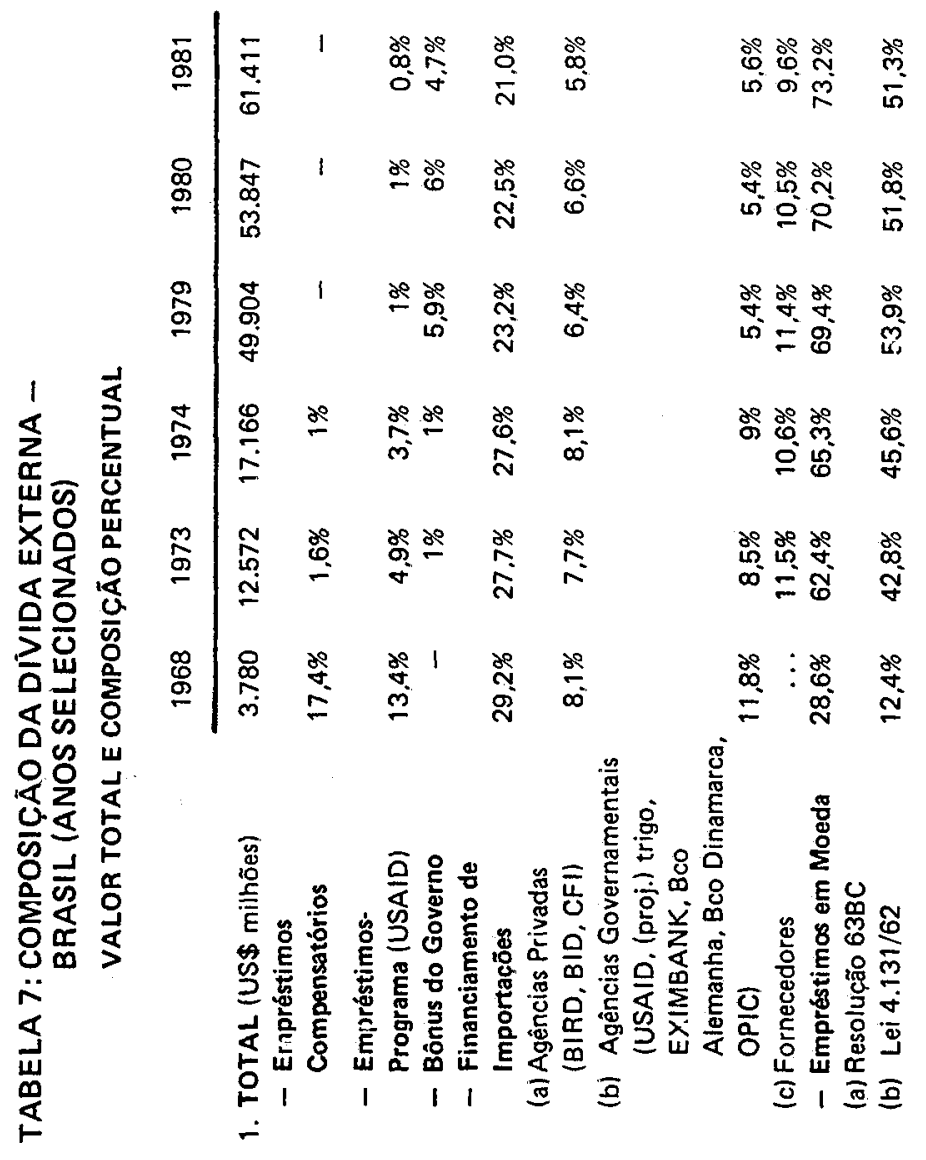

